\title{
Erratum to: "Assessment of Variations in the Annual Sum of Active Temperatures and Total Precipitation during the Vegetation Period in Russia and Neighboring Countries" [Russian Meteorology and Hydrology 43(6), 412-417, 2018] E. N. Popova ${ }^{a, b *}$, I. O. Popov ${ }^{b}$, and S. M. Semenov ${ }^{a, b}$ \\ ${ }^{a}$ Institute of Geography, Russian Academy of Sciences, Staromonetnyi per. 29, Moscow, 119017 Russia \\ ${ }^{b}$ Institute of Global Climate and Ecology of Roshydromet and Russian Academy of Sciences, ul. Glebovskaya 20b, Moscow, 107258 Russia \\ *e-mail: en_popova@mail.ru \\ Received November 15, 2017
}

DOI: $10.3103 / \mathrm{S} 1068373918080095$

In this article the true affiliation is

\author{
E. N. Popova ${ }^{a, b}$, I. O. Popov ${ }^{b}$, and S. M. Semenov ${ }^{a, b}$ \\ ${ }^{a}$ Institute of Geography, Russian Academy of Sciences, Staromonetnyi per. 29 , \\ Moscow, 119017 Russia \\ ${ }^{b}$ Institute of Global Climate and Ecology of Roshydromet and Russian Academy of Sciences, \\ ul. Glebovskaya 20b, Moscow, 107258 Russia \\ *e-mail:en_popova@mail.ru
}

The original article can be found online at 10.3103/S1068373918060092. 